sonores et audiovisuelles, des écrits et entretiens des praticiens, des archives journalistiques et des textes critiques. Elle propose une analyse nuancée, appuyée par d'abondantes ressources documentaires qui mettent en relief des aspects moins connus de l'histoire du théâtre qui se pratique à Montréal entre 1940 et 1980 . Finaliste pour un Prix du Canada en sciences humaines de la Fédération canadienne des sciences humaines en 2013, l'auteur propose avec cet ouvrage une lecture fascinante d'une époque effervescente de l'histoire théâtrale et culturelle montréalaise.

\title{
MICHELLE MACARTHUR, LYDIA WILKINSON, and KEREN ZAIONTZ, eds. \\ Performing Adaptations: Essays \& Conversations on the Theory and Practice of Adaptation.
}

Newcastle upon Tyne: Cambridge Scholars Publishing, 2009. 273 pp.

YANA MEERZON

The title of the edited collection, Performing Adaptations: Essays do Conversations on the Theory and Practice of Adaptation, promises an unusual format for an English-language scholarly publication. It suggests a free assembly of scholarly essays, conversations, interviews, artistic statements, and other materials related to the subject. Although such a format allows for a more creative approach, it also presents a challenge, specifically when a book is edited by emerging scholars. The co-editors, however, managed the task elegantly by selecting high quality articles and securing contributions from well-known and established scholars, such as Linda Hutcheon, Stephen Johnson, and Marlis Schweitzer, among others, as well as artistic statements from prolific American and Canadian theatre artists, experts in methodologies of adaptation for theatre, such as Tony Perucci, Marjorie Chan, George Elliott Clarke, and John Greyson, to name a few.

As the co-editors explain, the book stems from the 2006 Festival of Original Theatre: Adaptation in Performance, organized by the Graduate Centre for Study of Drama at the University of Toronto. Normally a collection of articles based on oral contributions presented at an academic gathering resembles conference proceedings. This book avoids that pitfall. It presents a well-balanced and thoughtful collection of contributions that complement one another. Specifically I would like to mention Stephen Johnson's article on Edwin S. Porter's cinematic rendering of Uncle Tom's Cabin. This essay provides insight on Edwin S. Porter's cinematic style and his personal traditions of adaptation. It also analyzes the episodic and improvisatory nature of this film's narrative that seems to be "at odds with mainstream theatre practice" of the time (87). This contribution is followed by two appendices, which also focus on theatrical adaptations of the novel. These chapters, however, appear to have been somewhat insubstantially contextualized by the co-editors. Publishing archival documents is a noble endeavour since public exposure to previously unknown material may lead to new and exciting theoretical inquiry. However, the book may fall short in this aspect unless the reader has studied multiple performance and cinematic renderings of Uncle Tom's Cabin.

The rest of the book presents a more successfully developed compilation. For instance, 
the volume sheds new light on the flourishing but rather convoluted discussion in literary studies on the artistic, social, and cultural value of adaptation. It considers the questions of fidelity, intermediality, appropriation, and cultural transposition of the original material into new contexts. The collection refreshes in a welcome fashion this somewhat tired argument by combining under one cover a number of scholarly contributions on this subject with interviews and other artistic reflections of several established Canadian theatre artists who have made adaptation their signature style. In this book the creators of adaptation and their critics speak together on the same subjects and sometimes about the same works, establishing practical and critical continuity on examine these issues. Hence, the book proposes a most fruitful approach to the issues of adaptation in theatre. It discusses adaptation as a methodological process of creating a theatrical performance, a process that remains interdisciplinary, collaborative, and unique to every production in question.

Furthermore, the book maps new territory in adaptation studies, focusing on Canadian theatre experiences and practices of adaptation. It reminds us that in the process of adaptation the voice of the adaptor takes over. Adaptation establishes the author/adaptor as an independent artist/creator of a new artistic product that in its own turn creates unique ties with the source material. Any adaption re-sets the creative process according to the artistic objectives of the target material and audiences. Specifically, these artistic reflections allow us to peek into the creative laboratories of such diverse theatre artists and writers as Beth Watkins, Modupe Olaogun, Ronald Wehs, and Atkina Stathaki. These contributions present a unique picture of how adaptation is practiced in today's theatre, ranging in its methodologies from borrowing to intertextuality and devised performance. The artists discuss the questions of parody, plagiarism, cultural and genre clichés, and the poetics of transgression as the necessary methodological and philosophical questions they face in the rehearsal hall when adapting their source material into a theatre performance.

The academic contributions vary in their context as well. They discuss a range of live and mediated performances focusing on the questions of how the techniques of spectatorship found in one media (from a live theatre performance to a video game) are used to recontextualize the source material into another media. They comment on political, methodological, and utilitarian functions theatre adaptation may have when it re-contextualizes chosen source material through the lenses of a new cultural context or another medium. For example, Natalie Corbett looks at techniques of remediation when a work of art moves from one artistic system into another. Her essay examines the systems of theatricality as they are found on stage and in a video game, as well as how the position of an audience member changes when he/she is confronted with a new system of artistic mediation. Alison Forsyth discusses re-mediations of Antigone as an example of theatrical adaptation that makes its creators and audiences think of war "in terms of human lives and suffering" (26). James McKinnon brings the discussion of adaptation techniques of canonical texts to Canada. By employing Genette's notion of paratext to study the prejudices paratextual materials can create, McKinnon argues that at the same time these materials - theatre programs, posters, interviews with directors and actors - can help adaptors to shape the projected critical reception of their audiences. Tom Stroud continues this line of inquiry by discussing the methodological issues of adapting canonical texts to the contemporary stage. In his contribution, Stroud taps into the understudied territory of adaptation in dance and examines the 
techniques of re-mediation when a Shakespearean play is moved from page to stage. As Stroud demonstrates, working in artistic forms so removed from each other as dramatic text and dance, "image can supplant the function of the narrative line while sustaining the integrity of the text" (59). Lawrence Howe concludes this line of academic inquiry by focusing on John Greyson's cinematic adaptations of Michel Marc Bouchard's dramaturgy. As he argues, cinematic adaptations, often better than original theatre plays or productions, can reveal sensitive social and political issues, including the questions of gender politics and institutional oppression. Specifically, he argues, "drawing on a striking range of intertextual procedures, Lilies subtly expands the scope of its criticism of homophobia in Canadian culture, rather than eliding or softening the critical stance of Bouchard's Les Feluettes" (204).

In conclusion, I would like to return to the premise of this edited collection, which reminds us that "live performance does not only offer a tool to analyze and explore types of adaptation but is essentially a type of adaptation itself" (xviii). In its interdisciplinary positioning, the art of adaptation borrows various story-telling devices of two or more performing media brought together or juxtaposed with each other in this gesture of moving stories across performing borders. By bringing together academic articles, archival materials, interviews, and primary texts of adaptations themselves, the collection successfully maps out a large and diverse territory of contemporary adaptation techniques in theatre, a welcome addition to this emerging field in theatre studies today.

NATALIE ALVAREZ, ed.

Fronteras Vivientes: Eight Latina/o Canadian Plays.

Toronto: Playwrights Canada Press, 2013. 460 pp.

\section{NATALIE ALVAREZ, ed. Latina/o Canadian Theatre and Performance.}

New Essays on Canadian Theatre, vol. 3. Toronto: Playwrights Canada Press, 2013. $268 \mathrm{pp}$.

\section{KATHERINE ZIEN}

The recent publication of two substantial volumes on Latina/o Canadian theatre marks one of the first concerted efforts to document, historicize, and critically locate practices and works of theatre and performance by, for, and about people of Latin American descent in Canada. Taken together, the scholarly essays in Latina/o Canadian Theatre and Performance (hereafter, LCTP) and the plays and contextualizing introductions in Fronteras Vivientes $(F V)$ deftly weave varied themes including political exile, gendered violence, indigeneity, and environmental hazards of mining into the production histories of Latina/o Canadian theatre companies. The texts relate this theatre scene to Latin American migration to Canada and the emergence of second-generation Latina/o Canadian theatre artists.

Canada's population of Latina/o citizens numbers roughly 527,000 as of the 2006 